19. Offshore Shell Games (2017). The Use of Offshore Tax Havens by Fortune 500 Companies. URL: https://itep.org/wp-content/uploads/offshoreshellgames2017.pdf.

20. Hidden Corners of the Global Economy. URL: https://www.imf.org/external/pubs/ft/ fandd/2019/09/pdf/fd0919.pdf.

21. Foreign direct investment, net inflows (BoP, current US\$). URL: https://data.worldbank. org/indicator/BX.KLT.DINV.CD.WD.

22. Paying Taxes (2018). URL: https://www.pwc.com/gx/en/paying-taxes/pdf/pwc_paying_ taxes_2018_full_report.pdf.

23. The Global Financial Centres Index 22 March (2019). URL: https://www.longfinance. net/media/documents/GFCI_25_Report.pdf.

24. Global Wealth (2019): Reigniting Radical Growth. URL: https://www.bcg.com/ publications/2019/global-wealth-reigniting-radical-growth.aspx.

25. Pidhurska, O. (2016). Tendentsii mizhnarodnoi ta natsionalnoi antyofshornoi polityky. Formuvannia rynkovoi ekonomiky v Ukraini: zb. nauk. pr./Lviv. nats. un-t im. I. Franka; [redkol.: S. M. Panchyshyn ta in.]. Lviv, Vyp. 35, ch. 2, P. $94-99$.

26. Svit proshchaietsia z of shoramy: Ukraina na cherzi. URL: https://www.epravda.com.ua/ projects/offshore/2019/10/21/652665/

27. FATF. What do we do. URL: https://www.fatf-gafi.org/about/whatwedo/\#d.en.3146.

28. High-risk and other monitored jurisdictions. URL: https://www.fatf-gafi.org/ publications/high-risk-and-other-monitored-jurisdictions/documents/fatf-compliance-october2019.html.

29. Tokmenko, V. V. (2014). Suchasnyi stan ta tendentsii hlobalnoho rehuliuvannia ofshornoho biznesu. Nauk. visn. Kherson. derzh. un-tu. Seriia: Ekonomichni nauky. Kherson, Vyp. 8, ch. 6, S. 35-38. URL: http://www.ej.kherson.ua/journal/economic_08/275.pdf.

30. Shokruta, V. Hlobalna deofshoryzatsiia, peredumovy yii vynyknennia. URL: http://yurgazeta.com/publications/practice/inshe/globalna-deofshorizaciya-ta-yiyi-vpliv-na-zed.html.

31. Ukraina i plan BEPS: chomu ofshory vidkhodiat u mynule. URL: https://www.epravda. com.ua/projects/offshore/2019/10/29/652879.

Матеріал надійшов до редакції 10.02.2020 p.

УДК 327:[314.743(477)+659.4]

\title{
Марина Пашкевич,
}

доктор економічних наук, професор, завідувач кафедри обліку і аудиту,

Національний технічний університет «Дніпровська політехніка»,

pashkevych.m.s@nmu.one

\section{Віктор Пашков,}

кандидат політичних наук, доцент кафедри обліку і аудиту,

Національний технічний університет «Дніпровська політехніка»,

https://orcid.org/0000-0003-4273-2181

viktor.pashkov.polit@gmail.com 


\title{
Дар'я Запорожець,
}

студентка 2 курсу спеціальності 291 «Міжнародні відносини, суспільні

комунікації та регіональні студії»

Національний технічний університет «Дніпровська політехніка»,

Zaporozhets.D.S@gmail.com

https://doi.org/10.29038/2524-2679-2020-01-40-52

\section{ДЕРЖАВА ТА ДІАСПОРА В МІЖНАРОДНИХ ВІДНОСИНАХ ХХІ СТ.: ЗАРУБІЖНИЙ ДОСВІД Й УРОКИ ДЛЯ УКРАЇНИ}

\begin{abstract}
Проаналізовано зарубіжний досвід формування державної політики щэодо національних діаспор на сучасному етапі. На прикладі Китаю, Угорщиини, Ізраїлю, Болгарії та інших країн виявлено основні інституційні, правові, гуманітарні й дипломатичні інструменти взаємодї держави та діаспори, щьо забезпечують просування національних інтересів краӥн на міжнародній арені, залучення ресурсів, кадрів $і$ зв'язків діаспор для розвитку історичної Батьківщини. Акиентовано увагу на необхідності формування інституційної системи такої взаємодії й системної державної політики для більш ефективного використання діаспори задля національного розвитку.

Виявлено, шо в геополітичних умовах XXI cm. все більше стають суб'єктами публічної дипломатії, «агентами впливу», які можуть не лише зміџнювати двосторонні відносини країн, формуючи транскордонні спільноти, а й поліпшувати міжнародний імідж краӥни.
\end{abstract}

Окремо проаналізовано вітчизняний досвід реалізачії політики щодо закордонних украӥнців: чинну нормативно-правову базу взаємодії з украӥнською діаспорою (Конституцію України, профільний закон та Державну програму співпраці із закордонними україниями на період до 2020 р.), стан та напрями державної політики в иій сфері, а також проблеми, які заважають Україні використовувати діаспору як ефективний зовнішньополітичний інструмент. Виявлено основні недоліки у вітчизняній державній політиці щзодо діаспори - розпорошеність взаємодії з діаспорою між багатьма державними відомствами, відсутність чіткої стратегії, передусім чіткого плану заходів, які повинен реалізовувати уряд, недостатнє фінансування, увага з боку держави.

На основі порівняння із зарубіжними практиками зроблено висновки та дано рекомендащії щзодо поліпшення ситуаџії, зокрема запропоновано створити окремий державний орган або агентство, яке б було відповідальне за взаємодію з діаспорою, а також на регіональному рівні потрібно реалізовувати проекти, націлені на залучення капіталу та інвестицій від представників діаспори, обмінюватися досвідом.

Ключові слова: діаспора, зовнішня політика, національні інтереси, двосторонні відносини, міжнародний імідж країни, публічна дипломатія.

\section{1. ВСТУП}

Постановка проблеми. В останні десятиріччя роль діаспор на міжнародній арені помітно зросла. Зовнішньополітичні практики багатьох країн світу все частіше включають у себе співпрацю 3 діаспорою. Останні стають субескктами публічної дипломатії, відіграють усе більшу роль у зміцненні звеязків з урядами, політичними партіями та громадськістю зарубіжних країн. Серед причин цього дослідники називають масштабні геополітичні зміни після

(С) Пашкевич М., Пашков В., Запорожещь Д., 2020 
розпаду СРСР, політика мультикультуралізму, яка існує в державах, де проживає багато мігрантів; новітні комунікаційні технології, котрі стали потужним засобом підтримання колективної ідентичності. Сьогодні більшість країн світу розробляють державні політики й механізми із взаємодії з власними діаспорами, розвиваючи тим самим політичну, бізнесову та культурну інтеграцію.

Україна за останні десятиріччя отримали власний досвід реалізації політики щодо закордонних українців, яка грунтується на визнанні їх частиною української світової спільноти. Однак, попри певні досягнення, взаємодія Української держави та діаспор поки що не є ефективною, а великий потенціал закордонного українства залишається практично незадіяним у розбудові країни. Тому аналіз зарубіжного досвіду в цій сфері, виявлення проблем і недоліків у вітчизняній державній політиці щодо діаспори є актуальним і корисним.

Аналіз останніх досліджень та публікацій. Проблематику взаємодії держави та діаспори розкривали у працях О. Лозовицький [9] та М. Трофименко [10]. Вітчизняні дослідники на теоретичному рівні аналізують роль діаспори як нового чинника зовнішньої політики країни, іiі трансформації 3 обеєкта етнонаціональної політики, на субеєкта публічної дипломатії. Серед західних дослідників теоретичні питання нової ролі діаспор на міжнародній арені розглядають Ф. Адамсон [13], Б. Мулінгс [14].

Закордонний досвід побудови співпраці держави та діаспори висвітлюють С. Коч [7] (на прикладі Болгаріï), А. Сергєєва [11] (на прикладі Китаю), М. Томіжек [15]. Актуальні проблеми становлення вітчизняної державної політики щодо діаспори аналізуються в працях А. Атаманенко [1], В. Бакальчук [2], Т. Гнатюк [3], О. Коляда [6], О. Лалак [8]. Для більшості авторів характерний емпіричний аналіз вітчизняної практики й стану відносин із діаспорою.

Мета дослідження - аналіз зарубіжного досвіду взаємодії держави та діаспори $з$ метою порівняння 3 вітчизняною практикою, виявлення проблем $\mathrm{i}$ недоліків у державній політиці України в цій сфері.

\section{2. РЕЗУЛЬТАТИ ДОСЛІДЖЕННЯ}

Наявність впливової діаспори за кордоном має великий вплив на розвиток дипломатичних відносин держави, іiі зовнішньої політики. Зважаючи на те, що останнім часом тенденції міграції лише поширюються, діаспора сприймається як впливовий фактор внутрішньополітичних процесів і міжнародної політики. Вона розглядається як потенційний дипломатичний актор, основними функціями якого є переговори, спілкування та представництво країни у світі.

Надважливе значення діаспора має для маленьких країн із невеликим державним бюджетом, оскільки діаспора може сприяти залученню інвестицій на розвиток країни, організовувати дипломатичні контакти. Так, діаспора Ізраїлю, Вірменії та Греції в США мають великий вплив на американський уряд 
щодо формування політики стосовно цих країн [1, с. 93]. 3 іншого боку, розвиток відносин діаспори з урядом ії історичної батьківщини так само $\epsilon$ надважливим.

Відносини за лінією «національний уряд-діаспора» встановлюються через міністерство закордонних справ, посольства, консульства, торгові палати. Співпраця діаспор із країнами походження відбувається в різних формах i напрямах, у тому числі через залучення співвітчизників із діаспор у політику, бізнес-проекти. Наприкінці XX ст. у багатьох державах світу створено окремі урядові органи та агентства, головним завданням яких стала робота із діаспорами. Державна політика 3 підтримки закордонних співвітчизників орієнтована на зміцнення національної єдності та залучення потенціалу діаспор для виконання завдань соціально-економічного та геополітичного розвитку.

Діаспора все більше стає субеєктом публічної дипломатії. Під останньою потрібно розуміти міжнародну діяльність, спрямовану на зміцнення зв "еязків між політичними субеектами й громадськістю зарубіжних країн, для більш кращого інформування закордонної аудиторії, впливу на неї. На сучасному етапі діаспору як інструмент забезпечення зовнішньополітичних інтересів активно використовують як великі держави (Китай, Індія), так і невеликі за розміром і населенням (Болгарія, Ізраїль, Греція, Угорщина).

У XX ст. міграційні процеси в Китаї значно активізувалися. Причини цього - революції, громадянські війни, голод, масові репресії. За останні 100 років із Китаю в різні регіону світу виїхало до 35 млн осіб [2, с. 95]. Тому уряд Китаю вважав за необхідне створити державні структури, які контролюватимуть взаємодію із закордонними китайцями. Зауважимо, що термін «хуацяо» в КНР уживається для двох категорій осіб: 1) громадян КНР, які постійно або дуже тривалий час мешкають за кордоном; 2) нащадків китайських емігрантів, які є громадянами своїх країн проживання. В останню чверть XX ст. у Китаї створено велику кількість державних і громадських організацій, ухвалено низку нормативно-правових актів, які забезпечували права вихідців із Китаю.

У 1980-х рр. уряд продовжував удосконалювати систему, яка займається справами закордонних китайців. Основним органом у цій системі є Канцелярія хуацяо при Державній раді КНР. Ї̈̈ функціями є розробка й реалізація політики щодо закордонних співвітчизників, організація конференцій, форумів, мета яких - їх залучення для обміну досвідом, підвищення рівня громадської обізнаності щодо співпраці з діаспорою. Канцелярії підпорядковується декілька навчальних закладів (Пекінський інститут китайської мови i літератури, Університет хуацяо).

На місцевому рівні також реалізовуються різноманітні проекти, ухвалено законодавство щодо залучення капіталів, технологій, спеціалістів із хуацяо. Для цього створюються платформи для спілкування, обміну досвідом державних органів із представниками діаспори, формуються умови для ведення бізнесу.

У 1983 р. при Постійному комітеті зібрання народних представників створено Комітет із справ китайських емігрантів. Комітет відповідає за 
розробку законопроектів щодо хуацяо, а також виконує представницькі функції. У 1988 р. при Народній політичній консультативній раді засновано Комітет з питань китайців, які проживають за кордоном. У 1995 р. його реорганізовано в Комітет зі справ співвітчизників Гонконгу, Макао та Тайваню. Його основними функціями $є$ забезпечення співробітництва закордонних китайців й уряду, їх участь у формуванні політичного курсу Китаю.

У 1990-х рр. у країні відновила політичну діяльність партія «Чжигундан», членами якої є переважно китайські емігранти, які повернулися на Батьківщину з-за кордону. Вона бере участь у розробці державної політики щодо закордонних співвітчизників. У 1980-х pp. iз початком періоду реформ відновила свою роботу Китайська асоціація репатріантів. Її створено в 1950 р., але в роки «Культурної революції» їі діяльність заборонено.

У 1990 р. створено Китайську асоціацію закордонного обміну, що займається встановленням контактів із закордонними китайцями, їх залученням до внутрішнього бізнесу й стимулюванням громадян КНР до співробітництва 3 компаніями закордонних співвітчизників у науково-технічній, економічній та культурно-освітній сферах. Окрім основних структур, існує велика кількість інших організацій i допоміжних структур із роботи 3 діаспорою. Між усіма структурами існує взаємодія. Однак це виключає недержавні обеєкти з розробки та прийняття рішень, що $є$ проявом монополізму з боку партійно-державних органів у розробці та реалізації політики щодо закордонних китайців.

Із моменту створення держава Ізраїль системно реалізовує дипломатичну стратегію підтримки єврейських громад по всьому світу, захисту іудаїзму як національної релігії та ідеології. На світовому рівні найвідомішою організацією з підтримки євреїв стали World Jewish Restitution Organisation та United Jewish Appeal [3, с. 494]. У багатьох країнах світу за підтримки Ізраїлю функціонують впливові єврейські громади та організації, які слугують провідниками інтересів історичної батьківщини у своїх країнах. Так, у США діє American Israel Public Affairs Committee. Він активно співпрацює 3 американським Конгресом, Адміністрацією президента США, ЗМІ та громадськими організаціями.

Цікавим прикладом впливу діаспори на державну політику є Вірменська діаспора. У середині 1990-х рр. ця держава опинилась у складній ситуації (війна у Нагорному Карабасі, економічна криза, дефіцит іноземних інвестицій, розкол політичної еліти). Вірменська діаспора вплинула на ситуацію. Її представники вели переговори з урядом США, результатом чого стало збільшення фінансової допомоги Вірменії (до \$240 млн) [4, с. 412]. Водночас, завдяки зусиллям вірменської діаспори, заблоковано американські програми допомоги для Азербайджану.

Угорська діаспора має чималу кількість представництв у сусідніх країнах, що стало результатом трагічних наслідків світових війн для угорців. Так, згідно з Тріанонським мирним договором 1920 р., Угорщина, яка виникла на руїнах імперії Габсбургів, утратила значну частину історичних територій. Вступаючи в Другу світову війну на боці Німеччини, угорці прагнули відновити історичну справедливість, однак у підсумку втратили ще частину земель. Як результат, 
наприкінці 2010-х рр. діаспори в сусідніх з Угорщиною країнах становлять у Румунії - близько 1,2 млн осіб, Словаччині - 460 тис., Сербії - 250 тис., Україні - 150 тис., Австрії - 55 тис., Хорватії - 14 тис. тощо. Ще понад 2,5 млн етнічних угорців протягом XX ст. покинули батьківщину в пошуках кращого життя. Так у США проживає 1,56 млн угорців, Канаді - 315 тис., Ізраїлі та Франції - по 200 тис., Німеччині - 120 тис., Бразилії - 80 тис., Росії - 76 тис. [5]

Велика чисельність діаспори дає змогу угорському керівництву ефективно використовувати іiі для реалізації своїх зовнішньополітичних амбіцій. У країнах Східної Європи Будапешт активно роздає угорські паспорти «співвітчизникам»,

просуває їх до місцевих органів влади, реалізовує національні інтереси. Часто такі дії супроводжуються вимогами до сусідів надати автономію районам, у яких компактно проживають угорські меншини.

У рамках цієї стратегії угорський уряд розробив низку правових механізмів. У їхніх рамках діє система спрощеного надання громадянства Угорщини членам угорської діаспори. Ця практика закріплена в конституції країни та профільних нормативно-правових актах. Також створено систему державних органів, які вирішують усі питання, пов язані з видачею угорських паспортів. Прагнучи легітимізувати свої дії, у 2015 р. Будапешт ініціював у СС питання ухвалення пакета «незаперечних прав національних меншин у Європі», однак безуспішно.

Прикладом подібних дій уряду Угорщини є ситуація в Трансильванії. Діаспора в цьому румунському регіоні сьогодні становить близько 700 тис. осіб. Більшість із них належать до стародавнього угорського субетносу - секеї, які культурно відрізняються від угорців, але офіційний Будапешт наполегливо відносить їх до співвітчизників. У 1952-1968 рр. регіон мав автономію, але згодом iї скасовано румунським диктатором Н. Чаушеску. Після розпаду соціалістичного табору й демократизації політичної системи в Румунії проблема знову нагадала про себе. Національна рада секеїв вимагала проголошення автономії, але Бухарест ці вимоги відкинув, але все ж таки був змушений надати максимально широкі права угорській діаспорі (право на подвійне громадянство, навчання рідною мовою, парламентське представництво, а також офіційний статус угорської мови в регіонах компактного проживання).

Схожу політику угорський уряд застосовує й щодо Сербії. Тривалий час після розпаду Югославії там існувала проблема правової неврегульованості громадянства, чим намагалася користуватись угорська влада. Щодо Словаччини та України, то тут стримувальним фактором для Будапешту $\epsilon$ заборона подвійного громадянства згідно із законодавством цих країн. Натомість Угорщина практикує тут видачу «угорських посвідчень» (документів для закордонних співвітчизників), а також угорських паспортів на Закарпатті. Отже, політика Угорщини щодо діаспори в сусідніх країнах $є$ складовою частиною стратегії національного розвитку та реалізується дуже агресивно на державному рівні. Фактично деякі дії угорської влади на території сусідів $\epsilon$ формами стимуляції сепаратизму, що створює певні проблеми для країн i вимагає від них відстоювання власних інтересів. 
У Республіці Болгарія протягом двох десятиліть формується механізм державного управління політикою щодо болгарських спільнот за кордоном. Інституційна система державних органів Болгарії включає вищі керівні органи, органи загальної компетенції й спеціалізовані органи. За різними даними, у світі проживає від 8 до 15 млн етнічних болгар, оскільки найбільша діаспора болгар за межами Болгарії наявна в Україні, що впливає на двосторонні відносини країн. Така ії роль зумовила тісний звеязок між діаспорою та батьківщиною протягом тривалого історичного часу. Досвід взаємодії став основою формування державної політики Болгарії стосовно співвітчизників за кордоном.

До 1989 р. Софія не проводила активної політики, яка б давала змогу країні підтримувати культурні й економічні зв"еязки 3 власною діаспорою. Оформлення політики Республіки Болгарії щодо «закордонних болгар» починається 3 1990-х pp., а на початку XXI ст. вона набула розвиненої інституційної структури. У цей період створено Всесвітню асоціацію та Всесвітній парламент болгар. Статут асоціації проголосив національну мету «вільна, незалежна, демократична й процвітаюча Болгарія, член ЄС духовно обеєднує болгарську націю та підтримує болгар у всьому світі». Метою Всесвітньої асоціації болгар визначено «лобіювання на користь болгарської нації та національної держави» [6, с. 140]. Наступний крок- Всесвітня зустріч болгар у Європейського парламенті в листопаді 2012 p. На зустрічі обговорювали політику щодо болгар за кордоном, визначили головні пріоритети - поширення болгарської мови, культури, традицій, віри. Зазначалося, що Болгарія повинна гарантувати фінансування болгарських шкіл за кордоном, лобіювати включення болгарської мови в програми шкіл країн $Є С$. Ще одним важливим пріоритетом стало формування постійного представницького органу - Національної ради болгар за кордоном.

У 2014 р. затверджено «Національну стратегію для болгарських громадян і болгарських історичних громад по всьому світу». Головним завданням нової стратегії став курс на інтеграцію всіх етнічних болгар за кордоном (3 млн осіб) у єдину болгарську націю. Для ефективної реалізації завдань національної стратегії створено низку державних структур. Так, при адміністрації Президента Болгарії з 22 травня 2012 р. діє Комісія 3 болгарського громадянства i болгар за кордоном. Дирекція «Міграція» в структурі Міністерства внутрішніх справ діє із 2004 р., регулює міграційну політику країни. Громадяни Болгарії та «особи болгарського походження» $є$ цільовими групами міграційної політики Болгарії, відповідно до положень «Національної стратегії». Також існує Міжвідомча комісія з питань болгар за кордоном при Міністерстві освіти, що координує забезпечення діяльності болгарських шкіл за кордоном.

Також успішним прикладом установлення партнерства національної держави та діаспори є Греція, у якій у рамках Міністерства закордонних справ працює Генеральний секретаріат у справах греків зарубіжжя - спеціальний урядовий орган. Він відповідальний за планування, координацію та реалізацію 
політики щодо грецької діаспори. Декретом Президента Греції в 1995 р. створено Раду греків зарубіжжя задля координації роботи та більш активного співробітництва грецького уряду й діаспори [7]. Головним іiі завданням $\epsilon$ просування інтересів Греції за кордоном, із чим вона справляється.

Світова українська спільнота $\epsilon$ однією 3 найбільших у світі та різноманітною за своїм розвитком. Певні негативні події в історії українського народу, вплив зовнішніх чинників призвели до того, що сьогодні близько третини українців проживає за межами рідної держави. За даними Світового конгресу українців (СКУ), кількість закордонних українців сьогодні доходить до 20 млн осіб, а за даними МЗС України чисельність української діаспори у світі оцінюються від 12 до 20 млн осіб [8, с. 9], не враховуючи трудових мігрантів. Станом на початок 2019 р. українці проживають у 130 країнах світу. У деяких із них українська громада давно пустила корені, але є й такі держави, що приймають українців уперше. Компактні українські громади $\epsilon$ в країнах Північної й Південної Америки, Близького та Далекого Сходу, Свропи, в Австралії, у країнах пострадянського простору. Національно-культурні об єднання українців функціонують у більш ніж 60 країнах.

Українська діаспора має великий вплив на міжнародне співтовариство, активно сприяє утвердженню позитивного іміджу історичної Батьківщини на міжнародній арені. За умов тісної співпраці закордонне українство може стати величезним ресурсом для України в реалізації зовнішньої політики, розвитку економічних i культурних відносин із зарубіжними країнами. Політичні звеязки, досвід, капітали, людський потенціал діаспор можуть стати потужним ресурсом прискорення соціально-економічної модернізації України, завершення демократичної консолідації та побудови успішної нації.

Державна політика України щодо закордонних українців грунтується на визнанні закордонних українців частиною української світової спільноти. Заходи, повеязанні зі співпрацею 3 діаспорою, відбуваються на основі відповідних положень Конституції України, Національної концепції співпраці iз закордонними українцями, Закону України «Про правовий статус закордонних українців», інших нормативно-правових актах. За необхідності, Україна може укладати угоди 3 іншими державами задля захисту діаспори. Найкращою моделлю співпраці 3 українською діаспорою $\epsilon$ не лише максимальне задоволення потреб закордонних українців, а й використання їхнього потенціалу для потреб України. Тому заходи повинні бути спрямовані на підтримку українських громад у світі та підтримку в задоволенні різноманітних потреб діаспори (освітні, культурні, фінансові), роботу з молоддю тощо.

У другій половині XX - на початку XXI ст. сформувалося декілька потужних центрів обеє єднання української діаспори. Найбільшою організацією міжнародного характеру є Світовий конгрес українців (СКУ), створений у НьюЙорку в 1967 р. Представництва СКУ координують свою роботу в більше ніж 60-ти країнах світу [9, с. 49]. Основними цілями СКУ є представництво інтересів українського народу у світі, підтримка незалежності та цілісності України, зміцнення звеязків українського народу 3 діаспорою, співпраця 3 урядами інших країн для досягнення миру, свободи й справедливості тощо. 
Європейський конгрес українців - організація, що представляє інтереси українських громад у країнах Центральної та Східної Свропи.

Українська всесвітня координаційна рада - основний координаційний орган закордонних українців. Це міжнародна спілка обееднань громадян, діяльність якої поширюється на територію України та інших держав. Мета організації - сприяння зміцненню незалежності України, сприяння співпраці України 3 міжнародними організаціями та країнами поселення українців. Найвищим органом управління УВКР $є$ Всесвітній форум українців, який скликається раз на чотири-п“ять років.

Відповідно до ст. 12 Конституції України, держава дбає про задоволення національно-культурних і мовних потреб українців, котрі проживають за ії межами [10, с. 19]. У 2004 р. ухвалено Закон України «Про закордонних українців». Згідно з ним, Українська держава має сприяти розвитку національної свідомості українців, які проживають за межами України, зміцненню їхніх зв язяків із батьківщиною, поверненню в Україну.

Уряд постановою від 10 травня 2018 р. № 344 затвердив «Державну програму співпраці із закордонними українцями на період до 2020 р.» [11], мета якої - забезпечення поглиблення співпраці із закордонними українцями шляхом підвищення ефективності роботи органів влади із закордонними українцями. Ïї реалізація сприятиме активізації співробітництва із закордонними українцями, задоволенню їхніх національно-культурних потреб, залученню потенціалу діаспори для утвердження позитивного іміджу України у світі, просування економічних інтересів держави. Основними завдання відповідно до програми є:

$>$ реалізація державної політики у сфері інформації щодо посилення протидії антиукраїнській пропаганді та утвердження позитивного іміджу України;

задоволення науково-освітніх потреб закордонних українців;

$>$ сприяння збереженню й розвитку української мови;

$>$ задоволення культурних потреб закордонних українців та збереження культурної спадщини;

$>$ поглиблення співпраці із закордонними українцями у сфері національнопатріотичного виховання.

Незважаючи на те, що Верховна Рада України визначила пріоритети й працює над законодавчою базою у сфері трудових міграцій, показники трудової міграції в Україні зростають, усе більше українців виїжджають за кордон у пошуках кращої долі. Деякі з них повертаються, деякі залишаються на чужині. Залучення українців з-за кордону вимагає чітких дій української влади, створення належних умов праці та проживання.

На превеликий жаль, в Українській державі наразі немає такого органу, який би повністю контролював роботу 3 діаспорою. Натомість ці функції розпорошені серед декількох державних органів. Управління 3 питань закордонного українства, гуманітарного співробітництва МЗС фокусується на питаннях співпраці із закордонними українцями. У Міністерстві соціальної політики працює відділ ліцензування діяльності з посередництва в 
працевлаштуванні за кордоном та 3 питань трудової міграції департаменту ринку праці та зайнятості [12, с. 35], у МОН - управління міжнародного співробітництва та європейської інтеграції. У структурі Верховної Ради діють декілька комітетів, робота яких опосередковано стосується діаспори.

Деякі закордонні українці, які покинули Україну, мають намір повернутися, працювати задля іï блага, але повільне просування реформ розчаровує українців за кордоном. Влада має докладати зусиль, щоб українці мали можливість повертатися додому, налагоджувати контакти, розповідати їм про життя за кордоном та спільно реалізувати проекти. Але, повертаючись в Україну, вони повинні бути впевненні, що тут їх чекають гідні умови праці та життя, яких, на жаль, поки українська влада не може гарантувати.

Реінтеграція трудових мігрантів стає дуже важливою для України. Тому Державна служба зайнятості створює центри розвитку підприємництва та модернізує соціальну допомогу для організації підприємницької діяльності, однак ефективність таких заходів ще недостатньо вивчена. Міністерство освіти i науки України співпрацює із закордонними українцями. Наприклад, діти українців, які проживають за кордоном, навчаються там, мають можливість навчатись у Міжнародній українській школі. Заклад співпрацює із закордонними українськими організаціями, школами [13, с. 59]. Також МOH працює над розробкою навчальних матеріалів для вивчення української як іноземної мови за кордоном.

Багато українських студентів їдуть здобувати освіту за кордон і їх кількість невпинно зростає, що зумовлено деякими причинами, як-от: недостатній рівень здобуття освіти в українських навчальних закладах, активна агітація українських студентів деякими країнами $\mathrm{CC}$ щодо здобуття освіти тощо [14, с. 37]. Велика кількість студентів, здобувши освіту за кордоном, повертається на Батьківщину. Тому заходи державної політики мають бути спрямовані на ефективне використання досвіду, навичок і знань, які студенти отримали за кордоном, та надання цим особам робочих місць.

На сьогодні уряд України має певне уявлення щодо розвитку державної політики стосовно діаспори, котре закріплене в Державній програмі співпраці із закордонними українцями. У стосунках із закордонними українцями Україні потрібно брати до уваги досвід інших держав світу. Потрібно вдосконалювати роботу консульств, дипломатичних представництв, проводити інформаційну агітацію серед діаспори щодо залучення закордонного досвіду на території України.

\section{3. ВИСНОВКИ ТА ПЕРСПЕКТИВИ ПОДАЛЬШИХ ДОСЛІДЖЕНЬ}

Незважаючи на те, що взаємодія уряду із закордонними українцями має певне правове врегулювання (ЗУ «Про правовий статус закордонних українців», концепція співпраці з діаспорою, державна програма), державна політика в цьому напрямі поки що не приносить помітних результатів. Це відбувається через розпорошеність взаємодії з діаспорою між багатьма 
державними відомствами, відсутність чіткої стратегії, чіткого плану заходів, які повинен реалізовувати уряд, недостатнє фінансування цих заходів, увага з боку держави.

Тому, на нашу думку, доцільно було б створити окремий державний орган або агентство, яке б було відповідальне за взаємодію 3 діаспорою. Також потрібно на регіональному рівні реалізовувати проекти, націлені на залучення капіталу та інвестицій від представників діаспори, обмінюватися досвідом. Державна політика щодо закордонних українців повинна бути націлена передусім на створення в них мотивації повертатися на Батьківщину, тому українська влада повинна прагнути забезпечити закордонних українців соціальними перспективами та гарантіями того, що саме в Україні вони матимуть гідний рівень життя, самореалізацію країни, публічну дипломатію.

\section{СПИСОК ВИКОРИСТАНИХ ДЖЕРЕЛ}

1. Трофименко, М. (2019). Діаспора як обеєкт та субеєект публічної дипломатії. Історико-політичні проблеми сучасного світу, № 39, 92-101.

2. Сергеева, А. А. (2016). «Пять мостов», осуществляющих работу в КНР по взаимодействию с зарубежными соотечественниками. Вестник РГГУ. Политология. История. Международные отношения, № 3 (5), 94-101.

3. Adamson, F. B. (2007). «Remapping the boundaries of «state» and «national identity»: Incorpo-rating diasporas into IR theorizing». European Journal of International Relations, № 13, 489-526.

4. Mullings, B. (2012). "Governmentality, diaspora assemblages and the ongoing challenge of ,development». Antipode, № 44 (2), 406-427.

5. Як «відроджуються» імперії. Навіщо Угорщина надає своє громадянство діаспорі. URL: http://bintel.com.ua/uk/article/sichen10_31/

6. Коч, С. В. (2018). Республика Болгария и «болгары зарубежья»: формирование политики взаимодействия. Вісник ОНУ ім. I. І. Мечникова. Соціологія і політичні науки. Т. 23, вип. 2 (31), 128-148.

7. Лозовицький, О. С. Діаспори в сучасному світі: чинник зовнішньої політики чи важіль впливу держави. URL: http:// academy. gov.ua /ej/ej 14/ txts/ Lozovitskiy.pdf

8. Атаманенко, А. (2015). Закордонне українство та Україна: проблеми та перспективи. Наукові записки наџіонального університету «Острозька академія». Серія «Історичні науки», Вип. 23, 7-13.

9. Гомотюк, О. (2014). Українська діаспора США у процесах українського державотворення: перспективи дослідження. Мандрівецьь, № 5, 48-53.

10. Лалак, О. (2013) Історико-ментальні засади формування української діаспори та інституційно-процедурні механізми взаємодії з Україною. Держава та регіони. Серія: Соціальні комунікації, № 3-4, 18-23.

11. Державна програма співпраџі із закордонними украӥнцями на період до 2020 р. URL: https://zakon.rada.gov.ua/laws/show/344-2018-\%D0\%BF

12. Гнатюк, Т. (2014). Політика України щодо закордонного українства: невикористаний потенціал для розвитку. Наукові пращі. Політологія, Вип. 236, Т. 248, 34-38.

13. Бакальчук, В. (2019). Основні завдання державної політики щодо закордонних українців: можливості та перспективи (на прикладі української діаспори в Румунії). Стратегічні пріоритети, № 1 (49), 58-64.

14. Коляда, О. (2018). Українська діаспора як чинник поглиблення зовнішньоекономічних відносин країни. Економіка і суспільство, Вип. 15, 33-39. 


\section{THE STATE AND THE DIASPORA IN INTERNATIONAL RELATIONS OF THE XXI CENTURY: FOREIGN EXPERIENCE AND LESSONS FOR UKRAINE}

The foreign experience of forming state policy on national diasporas at the present stage is analyzed. The examples of China, Hungary, Israel, Bulgaria and other countries reveal the basic institutional, legal, humanitarian and diplomatic instruments of interaction between the state and the diaspora, ensuring the promotion of national interests of the countries in the international arena, attracting resources, personnel and relations of the diasporas for the development of the historical Diaspora. . Emphasis is placed on the need to form an institutional system of such interaction and systemic state policy for more effective use of the Diaspora for national development.

It is revealed that in the geopolitical conditions of the XXI century. they are increasingly becoming subjects of public diplomacy, «agents of influence» who can not only strengthen countries' bilateral relations by forming cross-border communities, but also improve the country's international image.

Separately analyzed is the domestic experience in the implementation of the policy on foreign Ukrainians: the current regulatory framework for interaction with the Ukrainian diaspora (Constitution of Ukraine, profile law and the State program for cooperation with foreign Ukrainians for the period up to 2020), the state and directions of state policy in this field, and problems that prevent Ukraine from using the Diaspora as an effective foreign policy tool. The main deficiencies in the national state policy concerning the diaspora were revealed - the dispersed interaction with the diaspora among many state agencies, the lack of a clear strategy, first of all, a clear plan of measures to be implemented by the government, insufficient funding, and state attention.

Based on comparisons with foreign practices, conclusions and recommendations have been made to improve the situation, in particular it is proposed to create a separate state body or agency that would be responsible for interaction with the diaspora, as well as to implement projects aimed at attracting capital and investments from representatives of the diaspora at the regional level, to share experiences.

Key words: diaspora, foreign policy, national interests, bilateral relations, international image of the country, public diplomacy.

\section{REFERENCES}

1. Trofymenko, M. (2019). Diaspora yak obiekt ta subiekt publichnoi dyplomatii. Istorykopolitychni problemy suchasnoho svitu, № 39, 92-101 (In Ukrainian).

2. Sergeeva, A. A. (2016). «Pjat' mostov», osushhestvljajushhih rabotu v KNR po vzaimodejstviju s zarubezhnymi sootechestvennikami. Vestnik RGGU. Politologija. Istorija. Mezhdunarodnye otnoshenija, № 3 (5), 94-101 (In Russian).

3. Adamson, F. B. (2007). «Remapping the boundaries of «state» and «national identity»: Incorpo-rating diasporas into IR theorizing». European Journal of International Relations, № 13, 489-526 (in English).

4. Mullings, B. (2012). «Governmentality, diaspora assemblages and the ongoing challenge of ,development». Antipode. № 44 (2), 406-427 (in English).

5. Iak «vidrodzhuiutsia» imperii. Navishcho Uhorshchyna nadaie svoie hromadianstvo diaspori. URL: http://bintel.com.ua/uk/article/sichen10_31/

6. Koch, S. V. (2018). Respublyka Bolharyia y «bolhary zarubezhia»: formyrovanye polytyky vzaymodeistvyia. Visnyk ONU im. I. I. Mechnykova. Sotsiolohiia i politychni nauky, T. 23. Vyp. 2 (31), 128-148 (in Russian).

7. Lozovytskyi, O. S. Diaspory v suchasnomu sviti: chynnyk zovnishnoi polityky chy vazhil vplyvu derzhavy. URL: http://academy.gov.ua/ej/ej14/txts/Lozovitskiy.pdf (in Ukrainian) 
8. Atamanenko, A. (2015). Zakordonne ukrainstvo ta Ukraina: problemy ta perspektyvy. Naukovi zapysky natsionalnoho universytetu "Ostrozka akademiia». Seriia «Istorychni nauky», Vyp. 23, 7-13 (in Ukrainian).

9. Homotiuk, O. (2014). Ukrainska diaspora SShA u protsesakh ukrainskoho derzhavotvorennia: perspektyvy doslidzhennia. Mandrivets, № 5, 48-53 (in Ukrainian).

10. Lalak, O. (2013). Istoryko-mentalni zasady formuvannia ukrainskoi diaspory ta instytutsiino-protsedurni mekhanizmy vzaiemodii z Ukrainoiu. Derzhava ta rehiony. Seriia: Sotsialni komunikatsii, 2013, № 3-4, 18-23 (in Ukrainian).

11. Derzhavna prohrama spivpratsi iz zakordonnymy ukraintsiamy na period do $2020 \mathrm{r}$. URL: https://zakon.rada.gov.ua/laws/show/344-2018-\%D0\%BF (in Ukrainian)

12. Hnatiuk, T. (2014). Polityka Ukrainy shchodo zakordonnoho ukrainstva: nevykorystanyi potentsial dlia rozvytku. Naukovi pratsi. Politolohiia, Vyp. 236, T. 248, 34-38 (in Ukrainian).

13. Bakalchuk, V. (2019). Osnovni zavdannia derzhavnoi polityky shchodo zakordonnykh ukraintsiv: mozhlyvosti ta perspektyvy (na prykladi ukrainskoi diaspory v Rumunii). Stratehichni priorytety, № 1 (49), 58-64 (in Ukrainian).

14. Koliada, O. (2018). Ukrainska diaspora yak chynnyk pohlyblennia zovnishnoekonomichnykh vidnosyn krainy. Ekonomika i suspilstvo, Vyp. 15, 33-39 (in Ukrainian).

Матеріал надійшов до редакції 04.02.2020 p.

УДК 314.151.3-054.7:504.7

Наталія Романюк,

кандидат географічних наук, доцент кафедри

міжнародних відносин та регіональних студій,

Східноєвропейський національний університет імені Лесі Українки,

43024, Україна, Волинська обл., м. Луцьк, вул. Винниченка, 28, каб. 201

ronaiv1972@mail.com

https://orcid.org/0000-0003-0682-1793

https://doi.org/10.29038/2524-2679-2020-01-52-61

\section{ВПЛИВ ГЛОБАЛЬНОГО ПОТЕПЛІННЯ ТА ЗМІН КЛІМАТУ НА ПОЯВУ КЛІМАТИЧНИХ МІГРАНТІВ}

Визначено основні причини та особливості прояву процесу глобального потепління й зміни клімату. Охарактеризовано природні та антропогенні фактори, які впливають на глобальне потепління й зміни клімату. Наведено приклади кліматичних змін у різних регіонах світу, охарактеризовано їх наслідки. Проаналізовано вплив глобального потепління та змін клімату на міграџійні процеси у світі. Розглянуто різні підходи щоодо того, як називати людей, котрі перемімуються через кліматичні зміни: кліматичні мігранти, екологічні мігранти, кліматичні біженці, біженці через зміни клімату. Акиентовано увагу на тому, що міграційні процеси, які відбуваються через глобальне потепління цे зміни клімату, пов'язані, передусім, із внутрішніми переміщеннями людей. А щубб бути біженцем, потрібно перебувати за межами своєї країни проживання, тому кліматичними біженцями, або біженцями через зміни клімату, їх вважати не можна. Наведено приклади прогнозів експертів щуодо кліматичних мігрантів як у випадку погіршення ситуачії зі зміною клімату, так $i$ у випадку ї̈ покращення.

(C) Романюк Н., 2020 